DOI: $10.4274 /$ tpa. 190

\title{
Neonatal diabetes mellitus
}

\author{
Mustafa Aydın, Ayşegül Zenciroğlu, Zehra Aycan*, Semra Çetinkaya*, Nilay Hakan, Nurullah Okumuş, \\ Belma Sayglı Karagöl, Ramiz Coşkun Gündüz \\ Dr. Sami Ulus Gynecology and Obstetrics, Pediatric Health and Diseases Education and Research Hospital, Department of Neonatology, Ankara, Turkey \\ ${ }^{\star}$ Dr. Sami Ulus Gynecology and Obstetrics, Pediatric Health and Diseases Education and Research Hospital, Pediatric Endocrinology, Ankara, Turkey
}

\section{Summary}

Neonatal diabetes is a monogenic disease causing cellular and functional defects in pancreatic $\beta$-cells seen at first six months of life. It has an estimated prevalence of 1 in 400 000-500 000 live births. Mutations in KCNJ11, ABCC8, and INS are the cause of neonatal diabetes mellitus in about $50 \%$ of patients. We present a rare case of neonatal diabetes mellitus in the light of the literature. A 32-day-old male infant born at $37^{\text {th }}$ weeks of gestation with a $1400 \mathrm{gr}$ birth weight was referred to us because of the persistent hyperglycemia. The patient whose body weight was $1460 \mathrm{gr}$ presented with decreased subcutaneous adipose tissue, bilateral criptorchidism and micropenis, and also III/ $\mathrm{Vl}^{\circ}$ systolic murmur in the mesocardiac region. On laboratory investigations, blood glucose levels were high (340-431 mg/dL), serum and urine ketone were negative, insulin and C-peptid levels were low $(<2 \mathrm{mU} / \mathrm{mL}$ and $<0.1 \mathrm{ng} / \mathrm{ml}$, respectively) and anti-insulin, anti-islet cell and anti-glutamic acid decarboxylase antibodies were negative. Despite the regulation of diet and insulin therapy a good glucose control could not be achieved and the patient died on the $83^{\text {rd }}$ postnatal day because of an overwhelming infection. (Turk Arch Ped 2012; 47: 137-9)

Key words: ATP-sensitive potassium channel, genetic testing, insulin, neonatal diabetes mellitus, sulfonylurea

\section{Introduction}

Neonatal diabetes is a monogenic disease occuring in the first 6 months of life with functional or cellular disorders in the pancreatic beta-cells (1-3). Kitselle (4) described the disease in 1852 for the first time in his son. Its prevalence has been reported to be 1 in 400 000-500 000 live births. It has two clinical subtypes including transient and persistent diabetes. Diabetes is persistent in about $70 \%$ of the cases $(1,2,5,6)$. Although mutations are present in KCNJ11, ABCC8 and INS genes in approximately half of the cases with neonatal diabetes, the cause is still not known in about 30\% (1-3).

Here, a newborn with a diagnosis of neonatal diabetes was discussed under the light of source information, since neonatal diabetes is observed rarely.

\section{Case}

A 32-days-old male patient who was delivered via cesarean section because of anhyrdramnios in the mother at the $37^{\text {th }}$ gestational week with a birth weight of $1400 \mathrm{~g}\left(<10^{\text {th }}\right.$ percentile) from the first pregnancy of a 23-year-old mother was referred to our clinic because his blood sugar measurements were found to be high. It was learned from his history that his blood sugar levels were high since his birth, could not be controlled well despite insulin treatment and dehydratation episodes developed intermittently. On physical examination of the patient who had a body weight of $1460 \mathrm{~g}$, subcutaneous fat tissue was found to be decreased and umbilical hernia was present (Picture 1). On cardiac examination, a grade III/IV systolic murmur was found on the mesocardiac focus. On the urogenital examination, the gonads were palpable bilaterally in the inguinal canals. There was no pathology on ophthalmologic examination. Other systems were found to be natural.

Laboratory tests showed that blood sugar levels were between 340 and $431 \mathrm{mg} / \mathrm{d} \mathrm{L}$ and serum and urine ketone were negative. Serum insulin level was found to be $<2 \mathrm{mU} / \mathrm{mL}$ (normal: 2.6-27). C-peptide level was found to be $<0.1 \mathrm{ng} / \mathrm{mL}$ (normal:0.9-4) and anti-insulin (AIA), islet (ICA) and glutamic acid decarboxylase (GAD) antibodies were found to be negative.

Address for Correspondence: Mustafa Aydin MD, Dr. Sami Ulus Gynecology and Obstetrics, Pediatric Health and Diseases Education and Research Hospital, Department of Neonatology Ankara, Turkey Phone: +90 3123056283 Fax: +90 3123170353 E-mail: dr1mustafa@hotmail.com Received: 05.21.2010 Accepted: 07.22.2010 
Serum calcium level was found to be $6.3 \mathrm{mg} / \mathrm{dL}$ (normal: 8.5-10.5), phosphorous was found to be $4.1 \mathrm{mg} / \mathrm{dL}$ (normal: 4.5-6.7) and magnesium was found to be $0,67 \mathrm{mmol} / \mathrm{dL}$ (normal: $0.7-0.86$ ). Thus, parathyroid hormon and $25-\mathrm{OH}$ vitamin $D$ levels were measured and found to be $4.25 \mathrm{pg} / \mathrm{mL}$ (normal: $10-65$ ) and $81.3 \mu \mathrm{g} / \mathrm{dL}$ (normal: 10-80), respectively. Anti-microsomal and anti-thyroglobulin antibodies were found to be negative. PTH level was found to be $39.1 \mathrm{pg} / \mathrm{mL}$ (normal: 11-67) and 25-OH vitamin D level was found to be $10 \mu \mathrm{g} / \mathrm{dL}$ (normal: 10-80) in the mother and calcium, phosphorous and thryoid hormon levels were found to be normal. Calcium gluconate/lactate and active vitamin $\mathrm{D}$ were given for hypocalcemia related to hypoparatyroidism. Magnesium sulphate was given for hypomagnesemia. After magnesium treatment magnesium level was found to be $0,76 \mathrm{mmol} / \mathrm{dL}$ and PTH level was found to be $11.2 \mathrm{pg} / \mathrm{mL}$. Thyroid functions of the patient whose general status was moderate/poor and who had sepsis were interpreted as "sick thyroid syndrome". L-Thyroxine treatment was started, since total T4 decreased during the follow-up.

Luteinizing hormon (LH), follicle stimulant hormon (FSH), 17-hydroxyprogesteron (17-OH progesteron), dihydroepiandrosterone sulphate (DHEA-SO4) and testosterone levels which were measured becuse of bilateral undescended testes and micropenis (streched penis length $1.5 \mathrm{~cm},<10^{\text {th }}$ percentile) were found to be normal and a $46, X Y$ kariotype was found. On pelvic ulrasonography, a structure compatible with the prostate was observed behind the bladder. On scrotal ultrasonography, the testes were observed in both inguinal canals. Urinary-blood amino acid chromatography and "tandem" mass spectrometry were found to be normal, but blood lactate level was found to be $82.3 \mathrm{mg} / \mathrm{dL}$ (normal: 4.5-19). On hearing test, normal brainstem evoked responses were obtained in both ears. The pancreas could be visualized on abdominal ultrasonography. On echocardiography, a large ventricular septal defect, patent ductus and pulmonary hypertension were observed. Furosemid treatment was started for because of cardiac anomalies.

Subcutaneous crystallized insulin treatment $(1 \mathrm{U} / \mathrm{kg} / \mathrm{day}$, in four doses) was started because of high blood sugar. Since glycemic control could not be obtained, the dose of insulin was increased gradually up to $2 \mathrm{U} / \mathrm{kg} /$ day. When blood glucose

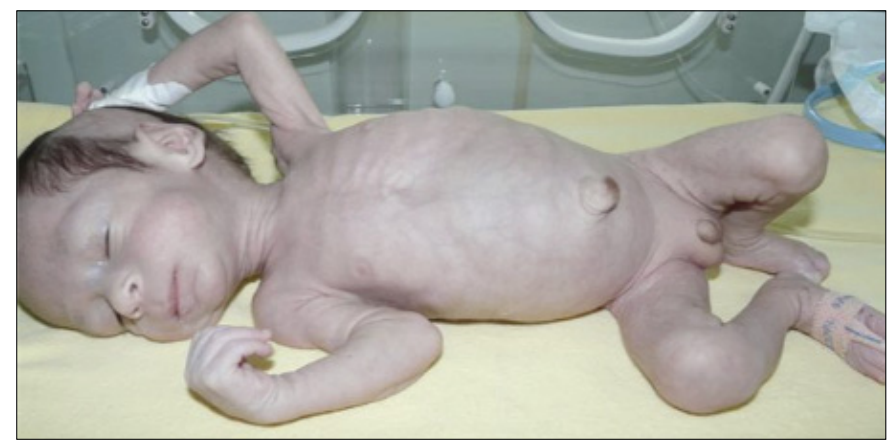

Picture 1. General appearance of the patient levels were high, additional $0.5 \mathrm{U}$ crystallized insulin was given. Since blood glucose levels were not desirable, insulin administered in the night was changed to NPH. Intravenous fluid and insulin infusion $(0.05-0.15 \mathrm{U} / \mathrm{kg} / \mathrm{h})$ was administered to the patient who developed dehydratation episodes and whose glycemic control was disrupted during intervening infections. In the clinical follow-up, intermittent dehydratation and fever episodes occured in the patient in whom glycemic control could not be obtained because of intervening infections. The patient died because of metabolic acidosis accompanying sepsis and intensive pulmonary hemorrhage on the $83^{\text {rd }}$ day of life.

\section{Discussion}

Diabetic newborns are generally born with low birth weight and at term. The clinical findings include weight loss, dehydratation, fever, reduced activity, hyperglycemia and acidosis which is usually not accompanied by ketonemia. Insulin secreted by the fetal pancreas has an important role in the growth and metabolism of the fetus especially in the second half of the pregnancy. Deficiency of insulin which is an anabolic hormon in the intrauterine period explains low birth weight observed in these cases $(7,8)$. Similarly, low birth weight in our patient can be explained by low insulin level.

There are still unknown points in the etiology of neonatal diabetes. It is a non-autoimmune, single gene disease. Autoantibodies against islet cell proteins are not present as in our case $(5,9)$. Neonatal diabetes is primarily a genetic disease and not a congenital form of type 1 diabetes. Studies have shown that diabetes might be arised from chromosome 6q24 abnormalities and mutations in the genes (KCNJ11 and $A B C C 8)$ coding glycolytic enzymes, glucokinase and two protein subunits (Kir6.2 and SUR1) of ATP-sensitive potassium channel (KATP) of the pancreatic $\beta$-cell. In addition, mutations in other genes (IPF1, PTF1A, FOXP3, GLIS3, TCF2, EIF2AK3) may also lead to multi-system diseases including neonatal diabetes $(1-3,5,10)$. In recent years, mutations which affect the structure and biosynthesis of insulin have been found in preproinsulin (INS) gene. Since normal folding of proteins will be disrupted as a result of these mutations, formation of proinsulin is disrupted and insulin production does not occur. The problem of folding in the molecule of proinsulin leads to destruction in the endoplasmic reticulum. This process causes a severe stress in the endoplasmic reticulum and leads to potential $\beta$-cell death by apopytosis $(2,3,5)$. In addition, Garin et al. (1) reported that recessive mutations in the insulin gene caused neonatal diabetes by decreasing the biosynthesis of insulin in an article which they published in 2010. However, there may still be unknown mutations in neonatal diabetes. No genetic analysis was performed in our case. However, in two newborns with neonatal diabetes who have not been published yet, deletion in exon 1-3 region of the insulin gene was found similar to Garin's study (1). 
Hypoparathyroidism may arise from the immature function of the parathyroid glands, hyperparathyroidism in the mother, aplasia or hypoplasia (DiGeorge/velocardiyofaciyal syndrome) of the parathyroid glands or magnesium deficiency. It may also be idiopathic (11). Correction of low PTH by magnesium treatment in our case suggested that this condition was related to magnesium deficiency. In addition, the picture of hypomagnesemia was assessed to be arisen from nutrition.

There is no clinical finding which can demonstrate that a case will be a transient or permanent case. In the follow-up of the patients, the fact that clinical findings did not improve and insulin was required for more than one year suggested permanent neonatal diabetes (8). Patients with transient neonatal diabetes have a heavier birth weight and they are diagnosed more lately. This finding is compatible with the information that deficiency of insulin is less severe in transient diabetes in which mutations result in low-degree funcional outcomes (1). Persistent neonatal diabetes was considered in our case, since the diagnosis was made immediately after birth and marked growth retardation was present. However, it could not be understood if this disorder was transient or not, since the patient was lost in the 3rd month of life.

Giralt et al. (12) described hypothyroidism, bilateral sensoryneural deafness and bilateral congenital cataract in a patient with permanent neonatal diabetes. Low thyroid hormon level in our case was evaluated to be "sick euthyroid syndrome". In addition, no hearing deficit was present in our case and ophthalmologic examination was found to be normal. In Wolcott-Rollison syndrome which is one of the syndromes progressing with neonatal diabetes, spondyloephyphyseal dysplasia, osteoporosis, recurrent fractures, hepatomegaly and renal failure are present. IPEX (immunodysregulation, polyendocrinopathy and enteropathy- $X$ linked inheritance) syndrome consists of refractory diarrhea, eczema, hemolytic anemia and autoimmune endocrinopathy $(10,13)$. Although bilateral undescended testes, micropenis and cardiac anomalies were present in our case, none of the abovementioned findings which are included in these syndromes was present and the clinical findings were not compatible with any other syndrome described so far. Although the association of neonatal diabetes related to pancreatic hypolasia and congenital cardiac anomaly has been described before, it has been stated that this condition might be a different clinical picture (14). Our case was not compatible with this condition, since congenital cardiac anomalies were present, but there was no pancreatic hypoplasia.

Newborns with diabetes require insulin treatment, but patients with mutations in KCNJ11 and ABCC8 genes can benefit from sulphonylurea. KATP channels have an important role in cellular response to metabolic changes in many organs especially in pancreatic cells which secrete insulin $(2,3,10)$. Klupa et al(15) reported that sulphonylurea treatment was efficient and safe in neonatal diabetes related to $\mathrm{KCNJ} 11$ gene mutation. Therefore, genetic testing should be considered in patients with a diagnosis of neonatal diabetes in terms of planning the appropriate treatment. Since genetic testing could not be done in our case and there is no approval of use, sulphonylurea treatment was not considered.

Neonatal diabetes is a genetic disease which occurs considerably rarely. Presentation of new cases with different clinical features will increase our information about this disease. In addition, definition of the underlying genetic cause will provide appropriate treatment approaches in these cases.

\section{References}

1. Garin I, Edghill EL, Akerman I, et al. Recessive mutations in the INS gene result in neonatal diabetes through reduced insulin biosynthesis. Proc Natl Acad Sci USA 2010;107:3105- 10.

2. Stoy J, Greeley SA, Paz VP, et al. Diagnosis and treatment of neonatal diabetes: a United States experience. Pediatr Diabetes 2008;9:450-9.

3. Colombo C, Porzio O, Liu M, et al. Seven mutations in the human insulin gene linked to permanent neonatal/infancy-onset diabetes mellitus. J Clin Invest 2008;118:2148-56.

4. Shield JP. Neonatal diabetes: new insights into aetiology and implications. Horm Res 2000;53 (Suppl 1):7-11.

5. Stoy J, Edghill EL, Flanagan SE, et al. Insulin gene mutations as a cause of permanent neonatal diabetes. Proc Natl Acad Sci U S A 2007;104:15040- 4

6. Aycan Z, Berberoğlu M, Ocal G, Altundas N, Adiyaman P, Evliyaoğlu O. Neonatal diabetes with hyperchylomicronemia. Indian $J$ Pediatr 2002;69:1087- 9.

7. Özlü $F$, Tiker F, Yüksel B. Neonatal diabetes mellitus. Indian Pediatr 2006;:43:642-5.

8. Güven A, Cinaz P, Bideci A. Yenidoğan diyabeti. T Klin J Pediatr 2003:12:199-205.

9. Gottschalk ME, Schatz DA, Clare-Salzler M, Kaufman DL, Ting GS, Geffner ME. Permanent diabetes without serological evidence of autoimmunity after transient neonatal diabetes. Diabetes Care 1992;15:1273-6.

10. Flechtner I, Vaxillaire M, Cavé H, Froguel P, Polak M. Neonatal diabetes mellitus: a disease linked to multiple mechanisms. Orphanet J Rare Dis 2007;2:12.

11. Doyle DA, DiGeorge AM. Disorders of the parathyroid. In: Behrman RE, Kliegman RM, Jenson HB (eds). Nelson textbook of pediatrics. 17th ed. Philadelphia: WB Saunders, 2004:1890-8.

12. Giralt Muina P, Sanchez Del Pozo J, Anaya Barea F, Garcia Silva M, Lledo Valera G, Rosa Garcia A. Permanent neonatal diabetes associated with other anomalies. An Esp Pediatr 2001;54:502-5.

13. Saka N, Baş F. Yenidoğan hipoglisemi ve hiperglisemileri. Dağoğlu T, Ovalı F (yazarlar). Neonatoloji. 2. baskı. İstanbul: Nobel Tıp Kitabevleri Ltd. Şti., 2008: 725-32.

14. Balasubramanian M, Shield JP, Acerini CL, et al. Pancreatic hypoplasia presenting with neonatal diabetes mellitus in association with congenital heart defect and developmental delay. Am J Med Genet A 2010;152A:340-6.

15. Klupa T, Skupien J, Mirkiewicz-Sieradzka B, et al. Efficacy and safety of sulfonylurea use in permanent neonatal diabetes due to KCNJ11 gene mutations: 34-month median follow-up. Diabetes Technol Ther 2010;12:387-91. 